Abstract P68 Table 1 Management of chlamydia positive patients

\begin{tabular}{llllcl}
\hline Year & $\begin{array}{l}\text { Site } \\
\mathbf{1} / \mathbf{2}(\%)\end{array}$ & $\begin{array}{l}\text { Age: median } \\
\text { (range) years }\end{array}$ & $\begin{array}{l}\text { CT positive } \\
(\%)\end{array}$ & $\begin{array}{l}\text { PN complete } \\
(\%)\end{array}$ & $\begin{array}{l}\text { Untreated } \\
(\%)\end{array}$ \\
\hline 2008 & $80 / 20$ & $22(19-40)$ & $13 / 647(2)$ & $4 / 13(31)$ & $5 / 13(38)$ \\
$2011 / 2012$ & $79 / 22$ & $33(14-84)$ & $16 / 889(1.8)$ & $12 / 16(75)$ & $3 / 16(18.7)$ \\
\hline
\end{tabular}

\section{P69 IN THOSE WITH HIGH WHITE CELL COUNTS PER HIGH POWERED FIELD DOES EXTENDED AZITHROMYCIN AFFECT PERSISTENCE/RECURRENCE}

doi:10.1136/sextrans-2012-050601c.69

A de Burgh-Thomas, ${ }^{*}$ A Ross Russell, K Maple, I Karunaratne. Gloucestershire Care Services, Gloucestershire Royal Hospital, Gloucester, UK

Aims We will compare the effect of an extended azithromycin (2 g of over several days) vs $1 \mathrm{~g}$ stat for those where $>50$ WCs per hi power field were found.

Methods We have reviewed all cases of NSU over a 3-month period following the introduction of extended treatment with azithromycin for those with hi levels of WCs per hpf. We will review the records of those patients diagnosed with NSU in previous years (over the same months) who were treated with regimes of either doxycycline $100 \mathrm{mg}$ twice daily for 7 days or azithromycin 1 g stat.

Results Following the change in policy half of all patients treated for NSU received an extended course. In the group who had hi levels of WC's $13 \%$ were subsequently found to be chlamydia positive by PCR and $87 \%$ were chlamydia negative. In the group with low levels of WC's $10 \%$ were chlamydia PCR positive and $90 \%$ were chlamydia negative. Of those with hi levels of WCs per HPF treated with a total of $2 \mathrm{~g}$ of azithromycin 18\% returned to clinic complaining of continuing symptoms. This compares to $20 \%$ with low levels of WCs per hi powered treated with the standard $1 \mathrm{~g}$ of azithromycin who suffered persistence/recurrence following treatment We will present data on those patient treated in previous years with both doxycycline and azithromycin at a dose of $1 \mathrm{~g}$.

Discussion So far we have analysed only those cases following the change in policy. We will present data that will demonstrate any change in response to extended azithromycin. The results will demonstrate whether the extended course has any benefits and at what cost.

\section{P70 NEISSERIA GONORRHOEAE ST26; EMERGENCE OF AN MSM ASSOCIATED STRAIN WITHIN A HETEROSEXUAL POPULATION DURING AN OUTBREAK}

doi:10.1136/sextrans-2012-050601c.70

${ }^{1} \mathrm{~J}$ Shone, ${ }^{*}{ }^{1} \mathrm{G}$ Orange, ${ }^{1} \mathrm{~S}$ Allstaff, ${ }^{1} \mathrm{C}$ Cunningham, ${ }^{1} \mathrm{D}$ Yirrell, ${ }^{2} \mathrm{~K}$ Eastick. ${ }^{1}$ Ninewells Hospital \& Medical School, Dundee, UK; ${ }^{2}$ Scottish Bacterial Sexually Transmitted Infections Reference Laboratory, RIE, Edinburgh, UK

Background Neisseria gonorrhoeae sequence type (ST) 26 has been documented across Scotland since the introduction of $N$ gonorrhoeae multi-antigen sequence typing (NG-MAST) in 2004. Scottish incidents of ST26 have historically been associated with men who have sex with men (MSM). In November 2010, it was noted that an increased proportion of ST26 isolates were documented among women within our local Health Board area.

Aims To explore the epidemiology of Scottish $N$ gonorrhoeae ST26 strains, with reference to a rising incidence of gonococcal (GC) diagnoses within our local area.

Methods All Scottish GC isolates (2004-2011), and nucleic acid amplification positive specimens where no isolate was available (2009-2011), were analysed by NG-MAST.
Results

Abstract P70 Table 1 Scottish incidences of Neisseria gonorrhoeae ST26 strains

\begin{tabular}{lllll}
\hline & $\begin{array}{l}\text { Local health } \\
\text { board }\end{array}$ & $\begin{array}{l}\text { Local health } \\
\text { board }\end{array}$ & $\begin{array}{l}\text { Non-local } \\
\text { health boards }\end{array}$ & $\begin{array}{l}\text { Non-local } \\
\text { health boards }\end{array}$ \\
\hline Time period & $\begin{array}{l}\text { Total } \\
\text { isolates }\end{array}$ & $\begin{array}{l}\text { Male } \\
\text { isolates }(\%)\end{array}$ & $\begin{array}{l}\text { Total } \\
\text { isolates }\end{array}$ & $\begin{array}{l}\text { Male } \\
\text { isolates (\%) }\end{array}$ \\
$2004-2007$ & 0 & - & 45 & 91.1 \\
2008 & 0 & - & 0 & - \\
2009 & 20 & 100 & 6 & 100 \\
January 2010-April 2010 & 3 & 100 & 6 & 83.3 \\
May 2010-0ctober 2010 & 0 & - & 0 & - \\
November & 32 & 56.3 & 2 & 50 \\
2010-September 2011 & & & & \\
Total & 55 & & 59 & \\
\hline
\end{tabular}

Discussion These data describe that up until November 2010, N gonorrhoeae ST26 in Scotland was predominantly found in men, indicating its association with MSM networks. The spike of ST26 strains in 2010/2011 in both men and women within our local Health Board area imply its introduction to a heterosexual network. These data demonstrate the utility of NG-MAST for the epidemiological study of GC infection. In particular, the data describe the manner in which gonococcal STs can become established and transferred between different regions and population groups, which may be assumed to have separate sexual networks.

\section{P71 VALIDATION OF AN IN HOUSE NUCLEIC ACID AMPLIFICATION (NAATS) PCR TEST FOR TRICHOMONAS VAGINALIS}

doi:10.1136/sextrans-2012-050601c.71

${ }^{1} \mathrm{~J}$ Appiah, ${ }^{* 2} \mathrm{P}$ Saunders, ${ }^{3} \mathrm{M}$ Yapa, ${ }^{3} \mathrm{C}$ Y W Tong, ${ }^{3} \mathrm{~J}$ White, ${ }^{2} \mathrm{C}$ Ison, ${ }^{2} \mathrm{~S}$ Alexander. ${ }^{1}$ Sexually Transmitted Bacteria Reference Laboratory, Health Protection Agency, London, UK; ${ }^{2}$ Health Protection Agency; ${ }^{3}$ Guys and St. Thomas Hospital NHS Trust, London, UK

Background Trichomonas vaginalis, a flagellated protozoan, is transmitted through sexual contact that commonly manifests itself as symptomatic in more women than men. However, the true prevalence of infection and the proportion that is asymptomatic is not known because of the lack of good diagnostic tests. Microscopy is the most common method of detection used but this is known to have a low sensitivity. Other methods include culture, which is considered the gold standard, a point of care test and molecular methods, which have increased sensitivity but are more time consuming or expensive.

Aim To validate an in-house nucleic acid amplification test (NAAT) test for the detection of $T$ vaginalis.

Method Two methods were established In-house. The first NAATs detected $T$ vaginalis by amplification of a $92 \mathrm{bp}$ segment of the $T$ vaginalis-specific repeat DNA fragment and the second amplified a segment of the â-tubulin gene, and was used to confirm the positive results. A further control ran alongside the first NAATs to identify inhibition by targeting the ribonuclease P gene. Sensitivity was initially validated with a positive control $T$ vaginalis strain $\mathrm{S} 1$ and then validated against anonimised clinical samples previously tested using the APTIMA $T$ vaginalis (ATV) transcription mediated amplification (TMA) kit and an in-house real-time TV PCR (see abstract P71 table 1). Results A total of 96 samples were tested. 17 (17.9\%) of the specimens tested resulted in positive $T$ vaginalis NAATs using both $T$ vaginalis real-time PCR and the TV confirmatory real-time PCR.

Conclusions These in house NAATs gave good concordance with the commercial assay. It would be useful to further compare detection between this and other methods including the culture and POCT in 